Volume 2 Nomor 2, Juli-Desember 2018: hlm. 111-120.

Magister Ilmu Hukum, Fakultas Hukum, Universitas Lampung,

Bandar Lampung, Lampung, Indonesia.

E-ISSN: 2598-3105 P-ISSN: 2723-2581

http://jurnal.fh.unila.ac.id/index.php/cepalo

\title{
ASAS TANGGUNG RENTENG PADA BENTUK USAHA BUKAN BADAN HUKUM DAN AKIBAT HUKUM BAGI HARTA PERKAWINAN
}

\section{THE PRINCIPLE OF JOINT LIABILITY IN NON-LEGAL ENTITY BUSINESS FORMS AND LEGAL CONSEQUENCES FOR MARRIAGES}

\author{
Rilda Murniati \\ Fakultas Hukum Universitas Lampung \\ Rilda_muniarti@ymail.com
}

\begin{abstract}
Abstrak
Bentuk usaha bukan badan hukum diatur dalam KUHD yaitu: firma dan CV yang memiliki hubungan komplementer yang harus menanggung tanggung jawab secara bersama-sama atas kerugian pada pihak lain secara pribadi dan bersifat keseluruhan. Permasalahan hukum yang mungkin timbul dalam hal sekutu komplementer tidak menimbulkan perjanjian kawin (pisah harta) sebelum perkawinan atau saat perkawinan berakibat hukum bagi harta bersama perkawinan. Dalam hal terjadi wanprestasi terhadap perjanjian yang dibuat untuk menjalankan kegiatan usaha dari bentuk usaha bukan badan hukum. Untuk itu, perlu diketahui bagaimana pengaturan asas tanggung renteng pada bentuk usaha bukan badan hukum dan dalam hal pengusaha mengelola perusahaan dan melangsungkan perjanjian dengan pihak lainnya hingga terjadi wanprestasi dan bahkan berakibat dipailitkan sehingga harta bersama perkawinan dapat ikut digunakan untuk melunasi utang perusahaan. Hal ini dapat terjadi jika, terbukti tidak adanya perjanjian perkawinan yang dibuat sebelumnya terhadap sekutu kompelementer tersebut sehingga istri/suami dapat turut digugat untuk dimintakan pertanggungjawaban dalam terjadi wanprestasi akibat perbuatan sekutu kompelementer untuk kepentingan perusahaan bukan badan hukum. Dengan adanya pembaruan hukum melalui Putusan Mahkamah Konstitusi No. 69/PUU-XIII/2015 sebagai judicial review atas Pasal 29 UU No.1 Tahun 1974, bahwa perjanjian kawin yang dapat dibuat oleh suami dan istri selaku sekutu komplementer selama berlangsungnya perkawinan di hadapan notaris adalah langkah antisipatif atas tanggung jawab secara tanggung renteng pada bentuk usaha bukan badan hukum yang berakibat bagi harta bersama perkawinan.
\end{abstract}

Kata Kunci: Sekutu Komplementer, Tanggung Renteng, Perjanjian Kawin.

Abstract

The form of business is not a legal entity regulated in the Criminal Code, namely: firms and CVs that have a complementary relationship that must bear joint responsibility for losses to other parties personally and overall. Legal issues that may arise in the case of complementary allies do not lead to marriage agreements (separation of assets) before marriage or when marriage has legal consequences for joint property of marriage. In the event of a default on the agreement made to carry out business activities from a non-legal entity business form. For this reason, it is necessary to know how the arrangement of joint responsibility principles in the form of non-legal entity business and in the case of entrepreneurs managing companies and entering into agreements with other parties until defaults occur and even result in bankruptcy so that joint property of marriages can be used to pay off corporate debts. This can happen if, as evidenced by the absence of a marriage agreement made earlier with the complementary allies so that the wife / husband can also be sued for accountability in the event of default due to the actions of the complementary allies for the benefit of the company not a legal entity. With the legal reform through the Constitutional Court Decision No. 69 / PUU-XIII / 2015 as a judicial review of Article 29 of Law No.1 of 1974, that a marriage agreement that can be made by a husband and wife as complementary allies during a marriage before a notary public is an anticipatory step towards joint responsibility in the form of joint responsibility in the form non-legal business entity which results in marital property.

Keywords: Complementary Allies, Joint Liability, Mating Agreement. 
Cara Mengutip (How to Cite): Rilda Murniati, "Asas Tanggung Renteng pada Bentuk Usaha Bukan Badan Hukum dan Akibat Hukum Bagi Harta Perkawinan”, Jurnal Cepalo, 2 (2), (2018): 111-120.

DOI: https://doi.org/10.25041/cepalo.v2no2.1768

\section{A. Pendahuluan}

Berbagai bentuk usaha dari perusahaan telah diatur oleh hukum, seperti dari segi hukum bentuk usaha dikelompokan dalam dua kelompok besar yaitu berbadan hukum dan bukan badan hukum. Pengelompokan hukum dari bentuknya tersebut didasarkan terpenuhinya syarat-syarat badan hukum yang ditemukan oleh doktrin ilmu hukum dan diatur pada setiap undang-undang yang mengatur bentuk usaha dari badan hukum tersebut. Syarat-syarat bentuk usaha digolongkan sebagai badan hukum yaitu apabila kekayaannya terpisah dari kekayaan para pendiri atau pengurusnya, serta Anggaran Dasar disahkan oleh Menteri dan memiliki organisasi untuk mencapai tujuan dari badan hukum tersebut.

Arti penting status bentuk usaha badan hukum pada perusahaan yaitu karena badan hukum adalah subjek hukum yang mampu melaksanakan urusan bisnisnnya sendiri karena memiliki hak dan kewajiban yang sama dengan manusia. ${ }^{1}$ Badan hukum harus dikelola oleh pengurus yang memilik wewenang mewakili badan hukum tersebut seusai dengan ketetapan dalam anggaran dasar. Untuk itu, segala kewajiban badan hukum yang dilaksanakan oleh pengurus menjadi beban badan hukum. Dalam kajian hukum perdata, perbedaan pokok dari pengelompokan perusahaan ke dalam bentuk usaha berbadan hukum dan bukan badan hukum adalah dari segi tanggung jawab pemilik atau pengurus dan harta kekayaan perusahaan. Syarat pertama yang menentukan suatu perusahaan digolongkan ke dalam bentuk usaha badan hukum yaitu pada ada, atau tidak ada pemisahaan harta perusahaan dan harta pribadi para pendiri, pemilik atau pengurusnya sehingga melahirkan konsekuensi hukum berupa tanggung jawab kepada pendiri atau pengurusnya atas setiap perbuatan hukumnya.

Pada perusahaan dengan bentuk usaha badan hukum, kewajibannya dapat terpenuhi dari aset yang dimiliki badan hukum itu. Sehingga kekayaannya tidak cukup untuk menutup kewajiban yang dimiliknya, maka kekayan pengurus ataupun pendirinya tidak bisa memenuhi kewajiban itu agar terhindar dari kepailitan atau kebangkrutan. ${ }^{2}$ Bagi perusahaan badan hukum tanggung jawab para pendiri dan pengurus telah diatur secara tegas dalam setiap undang-undang yang mengatur perusahaan badan hukum tersebut. Untuk itu, menjadi berbeda bagi perusahaan bukan badan hukum, dalam hal terjadi kerugian bagi pihak lain diatur oleh pendiri atau pengurusnya bertanggung jawab secara pribadi atas kerugian pihak lain. Hal ini dengan tegas diatur Pasal 18 Kitab Undang-Undang Hukum Dagang (KUHD) yang menjadi dasar hukum bagi perusahaan yang tidak berbadan hukum yaitu Firma bahwa "dalam perseroan firma adalah tiap- tiap pesero secara tanggung menanggung bertanggung jawab untuk keseluruhan atas segala perikatan dari perseroan". Sehubungan dengan itu, dalam Pasal 19 KUHD ditentukan bahwa Comanditaire Vennootschap (CV) atau Persekutuan Komanditer adalah firma dengan satu atau lebih sekutu komanditer. Sekutu komanditer (silent partner) adalah sekutu yang hanya memberikan pemasukan berupa uang, barang atau jasa dan tidak turut serta dalam mengurus persekutuan. Dia hanya menerima laba dari yang telah diberikannya itu. ${ }^{3}$ Untuk itu, pada CV terdapat dua macam sekutu yaitu sekutu komplementer (complementary partner) dan sekutu komanditer (silent partner). Dalam hal ini, yang bisa memiliki hubungan hukum dengan pihak ketiga hanyalah sekutu komplementer. Sekutu komplementer memiliki tanggung jawab secara keseluruhan sehingga pihak ketiga hanya bisa menagih kepada sekutu ini. ${ }^{4}$ Tanggung jawab tersebut bersifat pribadi untuk keseluruhan bagi setiap sekut kompementer yang ditentukan dalam Anggaran Dasarnya. Istilah hukum dalam pemberlakuan asas tanggung jawab pribadi bersifat keseluruhan dengan tidak adanya pemisahan harta perusahaan dengan harta pribadi pemilik atau pengurusnya pada perusahaan persekutuan bukan badan hukum dikenal dengan istilah asas tanggung renteng. Tanggung renteng dalam ensiklopedia artinya menanggung secara bersama-sama. ${ }^{5}$

Setiap pinjaman dana oleh Firma dan CV menjadi beban dan tanggung jawab pengurus atau pengelola secara pribadi. Tanggung jawab pribadi untuk keseluruhan pada bentuk usaha bukan badan hukum menjadi

\footnotetext{
${ }^{1}$ Abdulkadir Muhammad, Hukum Perusahaan Indonesia (Edisi Keempat Revisi), Bandung: Citra Aditya Bakti, (2010), hlm.101.

${ }^{2}$ Ibid.

${ }^{3}$ Ibid, hlm.93.

${ }^{4}$ Ibid, hlm.96.

${ }^{5}$ https://id.wiktionary.org, diakses pada tanggal 13 April 2017.
} 
masalah yang mungkin timbul dalam hal pinjaman dana tidak dapat dikelola dengan baik sehingga berlanjut dengan tidak dapat dikembalikannya pinjaman dana tersebut atau diajukan gugatan wanprestasi atau permohonan pailit oleh kreditornya. Untuk itu, dalam hal terjadi kerugian oleh perusahaan pada pihak lain maka harta pribadi pengusahanya atau pengurusnya akan ikut digunakan melunasi utang atau kerugian yang diderita oleh pihak lain tersebut sebagaimana ditentukan dalam KUHD. Dalam hal pendiri atau pengurus perusahaan telah terikat perkawinan maka tanggung jawab atau kerugian yang dialami perusahaan akan berakibat pada harta perkawinannya. Untuk itu, akan timbul permasalahan baru mengenai tanggung jawab pendiri atau pengurus pada bentuk usaha bukan badan hukum dari harta pribadi yang berstatus sebagai harta bersama perkawinan akan ikut disita akibat terjadinya wanprestasi dan atau kepailitan debitor selaku bentuk usaha bukan badan hukum.

Permasalahan hukum ini menjadi menarik untuk dilakukan kajian hukum terkait asas tanggung jawab secara tanggung renteng yang bersifat pribadi dan keseluruhan sebagai prinsip tanggung jawab pada bentuk usaha bukan badan hukum dengan tidak memisahkan harta milik pemilik atau pengurus dengan milik perusahaannya. Penelitian ini dilaksanakan untuk melakukan kajian dan analisis hukum mengenai pengaturan asas tanggung renteng dalam hal terjadi wanprestasi dan kepailitan pada perusahaan bukan badan hukum dan akibat hukumnya bagi harta bersama. Selanjutnya, dilakukan pula kajian dan analisis hukum mengenai aturan hukum baru sebagai penyelesaian hukum atas asas tanggung renteng sebagaimana hasil yudicial review terhadap Pasal 29 UU No.1 Tahun 1974 dalam putusan Mahkamah Konstitusi Nomor: 69/PPU- XIII/2015. Dalam penulisan ini digunakan metode hukum normatif dan pendekatan yuridis normatif dengan jenis penelitian deskriptif analitis, dengan menggunakan sumber data dari literatur, artikel dan situssitus internet.

\section{B. Pembahasan}

Pasal 1 Ayat (1) Undang-Undang Nomor 3 Tahun 1982 tentang Wajib Daftar Perusahaan, memberikan definisi resmi perusahaan adalah bentuk usaha yang bersifat tetap, terus-menerus, dan didirikan, bekerja serta berkedudukan dalam wilayah negara Indonesia dengan tujuan memperoleh keuntungan dan atau laba. Bentuk usaha dalam istilah pengganti dari perusahaan yang menjadi unsur penting dari perusahaan. Dalam arti bentuk usaha diatur oleh hukum dan setiap bentuk pasti memiliki kegiatan usaha di bidang ekonomi disebut perusahaan. Bentuk usaha adalah organisasi atau badan usaha yang menggerakan tiap-tiap kegiatan usaha. ${ }^{6}$ Dari segi hukum, bentuk hukum perusahaan dikelompokkan menjadi bentuk hukum perusahaan perseorangan, bentuk usaha bukan dan bentuk usaha badan badan hukum. Bentuk hukum perusahaan perseorangan belum diatur dalam undang-undang, tetapi dalam praktiknya di kehidupan masyarakat dibuat akta pendirian perusahaan perseorangan secara tertulis di muka notaris.

Perusahaan dengan bentuk usaha bukan badan hukum adalah perusahaan milik swasta yang didirikan oleh lebih dari satu orang pengusaha secara bersama. Bentuk perusahaan ini adalah perusahaan persekutuan di berbagai macam bidang perekonomian, antara lain: bidang perdagangan, perindustrian, dan perjasaan dan bentuk hukumnya adalah firma dan CV. Firma dan CV diatur dalam KUHD yang memiliki sekutu (pengusaha) yang menjalankan perusahaan dengan tanggung jawab sesuai dengan bentuk hukum Firma dan CV dengan karateristik sebagaimana diuraikan di bawah ini.

\section{Tanggung Jawab Sekutu secara Tanggung Renteng pada Bentuk Usaha Bukan Badan Hukum}

\section{a. Persekutuan Firma}

Firma adalah suatu perseroan yang didirikan untuk melakukan suatu usaha di bawah satu nama bersama (Pasal 16 KUHD). Firma memiliki sifat kekeluargaan. Hal ini dikarenakan sekutu dari firma itu sendiri adalah keluarga atau teman dekat yang bersama-sama menjalankan perusahaan untuk mendapatkn keuntungan. ${ }^{7}$ Berdasarkan pengertian ini, bahwa persekutuan itu disebut Firma apabila memiliki unsur pokok yaitu, perusahaan yang dijalankan bersama atau Firma yang tanggung jawab sekutunya bersifat pribadi untuk keseluruhan. Firma hanya mempunyai sekutu aktif atau sekutu komplementer dalam menjalankan perusahaan yang disebut firmant. ${ }^{8}$

Persekutuan Firma diatur dalam Pasal 16 sampai dengan Pasal 35 KUHD. tiga diantara pasal-pasal

\footnotetext{
${ }^{6}$ Abdulkadir Muhammad, Op.Cit., hlm.1.

${ }^{7}$ Zaeny Asyhadie, Hukum Bisnis dan Pelaksanaannya di Indonesia, Jakarta: Raja Grafindo, (2005), hlm.37-38.

${ }^{8}$ Abdulkadir Muhammad, Op.Cit., hlm. 88.
} 
tersebut yakni Pasal 19, 20, dan Pasal 21 KUHD adalah aturan untuk CV. ${ }^{9}$ Berdasarkan Pasal 18 KUHD, setiap sekutu bertanggung jawab bersama untuk seluruh perikatan Firma. Menurut seorang notaris dari Batavia bernama Van Ophuijsen, tanggung jawab para pihak kepada pihak ketiga tidak dilakukan secara langsung. Artinya semua utang firma dipenuhi dulu dengan uang kas firma. Jika uang kas tidak bisa menutupi baru diberlakukannya ketentuan Pasal 18 KUHD. ${ }^{10}$

\section{b. Persekutuan Komanditer (CV)}

Persekutuan komanditer atau disebut juga Commanditaire Vennootschap (CV). ${ }^{11} \mathrm{CV}$ adalah Firma yang memiliki satu atau lebih sekutu komanditer. Sekutu komanditer (silent partner) adalah sekutu yang hanya memberikan pemasukan berupa uang, barang, atau jasa tetapi tidak ikut serta dalam mengurus perseroan. Dia hanya menerima laba dari yang diberikannya. Tanggung jawabnya hanya sebatas jumlah yang diberikannya. ${ }^{12}$ Oleh karenanya, perbedaaan pokok CV dan Firma adalah pada sekutu komanditer tersebut.

Firma dan CV sebagai bentuk usaha bukan badan hukum memiliki pengaturan yang sama yang diatur dalam KUHD sehingga melahirkan berbagai persamaan dalam pendirian dan pengelolaan dengan perbedaann hanya pada pengaturan dan tanggung jawab bagi sekutu pasif atau sekutu komanditer yang ditentukan dalam Anggaran Dasar. Untuk itu, pada perusahaan bukan badan hukum terdapat 2(dua) jenis sekutu dengan tanggung jawab hukum yang berbeda sebagaimana ditentukan dalam KUHD, adalah sebagai berikut:

(1) Sekutu komplementer (complementary partner)

Sekutu komplementer adalah sekutu aktif yang menjadi pengurus pada Firma dan CV. Sekutu aktif disebut sekutu komplementer yang menanggung kerugian dan kekayaan dari Firma dan CV. ${ }^{13}$ Berdasarkan tanggung jawab tersebut, sekutu komplementer wajib menanggung utang dari Firma dan CV apabila tidak mampu untuk membayar utangnya. Hal ini dinyatakan secara tegas dalam Pasal 18 KUHD bahwa: "tiap-tiap persero bertanggung jawab secara tanggung renteng untuk seluruhnya atas perikatan-perikatan perseroannya". Ketentuan Pasal 18 KUHD inilah yang menjadi dasar hukum dari berlakunya asas tanggung renteng bagi sekutu aktif atau sekutu komplementer yang dimiliki oleh Firma dan CV. Sekutu aktif atau sekutu komplementer ini yang mampu mengadakan hubungan hukum dengan pihak ketiga. Pihak ketiga hanya bisa menagih sekutu komplementer karena sekutu inilah yang memiliki tanggung jawab secara keseluruhan. Bila sekutu komplementer lebih dari satu orang, maka diantara mereka harus ada yang tidak diperbolehkan bertindak keluar. Meskipun sekutu tersebut dilarang bertindak keluar, tetapi tanggung jawab yang dimilikinya tidak berubah sesuai yang ditetapkan dalam Pasal 18 KUHD. ${ }^{14}$

(2) Sekutu Komanditer (silent partner)

Adalah sekutu pasif yang tidak ikut serta pengurusan persekutuan. ${ }^{15}$ Sekutu inilah yang menjadi karakteristik pembeda Firma dengan CV. Dalam Pasal 19 KUHD, dinyatakan bahwa sekutu komanditer sebagai pemberi pinjaman uang. Selanjutnya ditegaskan bahwa sekutu komanditer tidak boleh mengurus atau bekerja dalam perusahaan, sekalipun diberi kuasa (Pasal 20 KUHD). Jika persekutuan menderita kerugian, sekutu komanditer hanya bertanggungjawab sesuai dengan pemasukan yang diberikannya. Sekutu komanditer tidak bisa dituntut menambah pemasukannya untuk menutupi kerugian dan diminta untuk mengembalikan laba yang telah diterima. Sekutu komanditer hanya memiliki tanggungjawab ke dalam yakni kepada sekutu komplementer dengan memberikan beberapa pemasukan. ${ }^{16}$

Dalam pengurusan perusahaan, sebagaimana ditegaskan dalam Pasal 19 KUHD bahwa sekutu komanditer tidak ikut dalam mengelola CV bahkan dengan surat kuasa dari sekutu komplementer yang berhak secara tegas tidak diperbolehkan. Untuk itu, kepengurusan bisa diawasi oleh sekutu komanditer apabila telah ditentukan dalam anggaran dasar CV. Apabila ketentuan ini dilanggar, Pasal 21 KUHD

\footnotetext{
${ }^{9}$ Ibid., hlm. 75.

${ }^{10}$ Pendapat van Ophuijsen, Ibid., hlm.93

${ }^{11}$ Zaeny Asyhadie, Op.Cit., hlm.38.

${ }^{12}$ Abdulkadir Muhammad, Op.Cit., hlm. 93

${ }^{13}$ Ibid.

${ }^{14}$ H.M.N. Purwosutjipto, Pengertian Pokok Hukum Dagang Indonesia 2: Bentuk-Bentuk Perusahaan, Jakarta: Djambatan, (2005), hlm.74.

${ }^{15}$ Ibid.

${ }^{16}$ Abdulkadir Muhammad, Op.Cit., hlm. 95.
} 
memberikan sanksi hukum yang tegas dan jelas yaitu “..bertanggung jawab secara tanggung renteng untuk seluruhnya terhadap semua utang dan perikatan perseroan itu..”.

Berdasarkan uraian di atas, maka dapat dinyatakan secara jelas dan terang KUHD sebagai dasar hukum bagi bentuk usaha bukan badan hukum yaitu Firma dan CV telah mengatur asas tangung jawab renteng bagi setiap sekutu aktif atau sekutu komplementer dalam hal timbul kerugian kepada pihak lain bersifat tanggung jawab pribadi dan keseluruhan. Bahkan tanpa kecuali bagi sekutu aktif yang dilarang melakukan perbuatan hukum tertentu bagi kepentingan perusahaan tetap dibebankan tanggung jawab renteng atas kerugian bagi pihak lain. Namunn demikian, dalam praktik dapat diterapkan terlebih dahulu kerugian yang diderita perusahaan ditanggung dari uang kas perusahaan dan selebihnya dibebankan secara tanggung renteng terhadap semua sekutu komplementer dan kewajiban ini tidak dibebankan kepada sekutu komanditer.

\section{Harta Bersama Perkawinan dalam UU No.1 Tahun 1974 dan Pembaharuan Hukumnya berdasarkan Putusan Mahkamah Konstitusi Nomor 69/PUU/XIII/2015}

Undang-Undang Nomor 1 Tahun 19974 tentang Perkawinan (UU No.1 Tahun 1974) adalah sumber hukum dari perkawinan dan hukum keluarga yang mengatur tentang perkawinan dan perceraian serta kehidupan keluarga dalam perkawinan bagi masyarakat Indonesia dan warga muslim yang menjadi mayoritas penduduk di Indonesia. ${ }^{17}$ UU No.1 Tahun 1974 mengatur pada asasnya perkawinan antara mempelai pria dan mempelai wanita mengakibatkan terjadinya persatuan harta kekayaan milik masingmasing. Namun kedua pihak diperbolehkan untuk mengadakan perjanjian perkawinan sebelum atau pada saat dilangsungkan perkawinan, asal diperbolehkan dalam undang-undang dan tidak bertentangan dengan ketertiban umum, agama, dan susila. Janji perkawinan yang dimaksud, misalnya perjanjian penggabungan harta kekayaan suami dan istri, suami tidak boleh menguasai harta milik istri tanpa persetujuan tertulis yang dibuat di muka notaris, dan suami atau istri beleh bersosialisasi dengan wanita atau pria lain di dalam kehidupan masyarakat. ${ }^{18}$ Perjanjian kawin adalah perjanjian yang mengatur mengenai harta benda calon suami istri yang dibuat sebelum atau pada saat dilangsungkan perkawinan. ${ }^{19}$

Setiap perkawinan akan menimbulkan harta perkawinan suami isteri seperti yang telah diatur dalam UU No.1 Tahun 1974 tetapi istilah yang digunakan bukanlah harta kekayaan dalam perkawinan, melainkan harta benda dalam perkawinan. Ini berarti UU No.1 Tahun 1974 melihat harta kekayaan perkawinan itu hanya berupa barang yang berwujud. ${ }^{20}$ Harta kekayaan dalam perkawinan diatur pada Bab VII tentang harta benda dalam perkawinan. Harta perkawinan adalah hak yang dimiliki bersama secara terikat, yang terjadi berdasarkan ketentuan UU No.1 Tahun 1974 atau karena perjanjian antara suami dan isteri. ${ }^{21}$ Berdasarkan Pasal 35 UU No.1 Tahun 1974 yang mengatur tentang harta dalam perkawinan dibedakan tiga jenis harta dalam perkawinan yaitu: Pertama, harta didapat suami dan istri selama perkawinan. Kedua, harta yang dibawa suami dan istri pada saat dilaksanakan perkawinan. Ketiga, harta yang didapat suami dan istri sebagai warisan atau hadiah. ${ }^{22}$

Harta bersama dalam perkawinan diatur dalam Pasal 35 Ayat (1) UU No.1 Tahun 1974 yang menentukan bahwa harta kekayaan yang didapat selama perkawinan menjadi harta bersama. Jika sebelum atau pada saat perkawinan dilaksanakan tidak adanya perjanjian antara calon suami dan calon isteri yang berkaitan dengan harta bendanya, maka menurut hukum harta benda akan dicampur menjadi harta bersama. ${ }^{23}$ Menurut ketentuan hukum, harta bersama antara suami dan isteri seluruhnya terjadi saat dilaksanakannya perkawinan. Harta bersama tersebut tetap berlangsung dan tidak bisa diubah selama perkawinan. ${ }^{24}$ Semua barang bergerak ataupun tidak bergerak yang dimiliki sebelum ataupun saat perkawinan serta yang nantinya akan didapat selama perkawinan termasuk ke dalam harta bersama. Namun terdapat Pengecualian apabila harta yang didapat merupakan pemberian untuk suami atau isteri baik dengan surat wasiat ataupun hibah, maka harta tersebut tidak masuk ke dalam harta bersama melainkan harta pribadi.

Menurut ketentuan Pasal 36 Ayat (1) UU No.1 Tahun 1974 dirumuskan bahwa suami dan isteri

\footnotetext{
${ }^{17}$ Abdulkadir Muhammad, Hukum Perdata Indonesia, Bandung: Citra Aditya Bakti, (2014), hlm.68.

${ }^{18}$ Ibid., hlm.83-84.

${ }^{19}$ Titik Triwulan Tutik, Hukum Perdata dalam Sistem Hukum Nasional, Jakarta: Kencana, (2008), hlm.120.

${ }^{20}$ J.Andy Hartanto, Hukum Harta Kekayaan, Bandung: Citra Aditya Bakti, (1994), hlm.38.

${ }^{21}$ Ibid., hlm. 67.

${ }^{22}$ Abdulkadir Muhammad, Hukum Perdata Indonesia, Op.Cit., hlm.109.

${ }^{23}$ J.Andry Hartanto, Op.Cit., hlm. 37.

${ }^{24}$ Jono, Hukum Kepailitan, Jakarta: Penerbit Sinar Grafika, (2013), hlm. 38.
} 
memiliki kuasa atas harta bersama dan hak dan kewajiban suami dan isteri atas harta bersama adalah sama. ${ }^{25}$ Jika terjadi perceraian, maka harta bersama dibagi sesuai hukum yang berlaku kepada suami dan isteri. ${ }^{26}$ Harta bersama bubar demi hukum karena kematian atau perceraian. Ketentuan dalam UU No. 1 Tahun 1974 telah mengatur secara tegas mengenai hukum perkawinan bagi setiap warga negara Indonesia termasuk mengenai perlunya dibuat perjanjian kawin atas harta bersama sebelum atau saat perkawinan dilaksanakan namun perjanjian ini tidak bisa dibatalkan. Hal ini menjadi masalah dalam hal calon suami dan calon istri tidak mengetahui atau mempersiapkannya terlebih dahulu sehingga jika akan dibuat kemudian setelah berlangsungnya perkawinan menjadi perjanjian kawin tersebut tidak sah atau batal menurut hukum.

Perjanjian perkawinan yang diatur dalam UU No.1 Tahun 1974 menjadi masalah kemudian hari dalam apabila terjadi perkawinan campuran (suami dan isteri berbeda warga negara). Perkawinan campuran dibolehkan dalam hukum Indonesia dan sehubungan pula adanya hukum Indonesia dengan berlakunya Peraturan Pemerintah Nomor 103 Tahun 2015 tentang Kepemilikan Rumah Tempat Tinggal atau Hunian oleh Orang Asing yang berkedudukan di Indonesia (PP No.103 Tahun 2015 tentang Pemilikan Rumah), yang merupakan peraturan pengganti dari Peraturan Pemerintah Nomor 41 Tahun 1996.

Pasal 3 Ayat (1) PP No.103 Tahun 2015 menentukan bahwa WNI yang melakukan perkawinan dengan WNA dapat memiliki hak atas tanah yang sama dengan WNI lainya apabila bukan merupakan harta bersama yang dibuktikan dengan perjanjian pemisahan harta antara suami istri, yang dibuat dengan akta notaris. Hak-hak ini meliputi: Hak Milik, Hak Guna Bangunan, dan Hak Guna Usaha. Oleh karena itu, WNI yang melakukan perkawinan dengan WNA tidak bisa menguasai tanah dengan Hak Milik apabila tidak ada perjanjian. ${ }^{27}$ Ketentuan dalam PP No 103 Tahun 2015 adalah peraturan penjelas dari ketentuan pokok dalam Pasal 21 Ayat (3) Undang-Undang Nomor 5 Tahun 1960 tentang Peraturan Dasar Poko-Pokok Agraria. Atas status perkawinan campuran pada seorang WNI dan tidak membuat perjanjian pada saat perkawinan maka WNI tersebut tidak dibenarkan oleh hukum positif yang berlaku untuk dapat memiliki harta kekayaan sebagai hak miliknya. Untuk itu, diajukanlah permohonan yudicial review ke Mahkamah Konstitusi RI untuk melakukan uji materi terhadap ketentuan mengenai perjanjian perkawinan dalam Pasal 29 Ayat (1), (2),(3), (4) UU No.1 Tahun 1974.

Pada tanggal 27 Oktober 2016, Mahkamah Konstitusi mengeluarkan Putusan Nomor 69/PUUXII/2015 yang pada pokoknya mengabulkan permohonan uji materi terhadap ketentuan tersebut sehingga ketentuan Pasal 29 berbunyi:

a. Sebelum dilaksanakan atau selama dalam ikatan perkawinan kedua pihak dengan persetujuan bersama dapat mengajukan perjanjian tertulis yang disahkan oleh pegawai pencatat perkawinan atau notaris, yang isinya berlaku juga terhadap pihak ketiga yang bersangkutan.

b. Perjanjian tersebut tidak dapat disahkan bilamana melanggar batas-batas hukum, agama, dan kesusilaan.

c. Perjanjian tersebut dimulai berlaku sejak perkawinan dilangsungkan, kecuali ditentukan lain dalam Perjanjian Perkawinan.

d. Selama perkawinan berlangsung, perjanjian perkawinan dapat mengenai harta perkawinan atau perjanjian lainnya, tidak dapat diubah atau dicabut, kecuali kedua belah pihak ada persetujuan untuk mengubah atau mencabut, dan perubahan atau pencabutan itu tidak merugikan pihak ketiga.

Dengan putusan Mahkamah Konstitusi (MK) No. 69/PUU-XIII/2015 yang secara jelas merubah dan menambah ketentuan dalam Pasal 29 UU No. 1 Tahun 1974 maka lahirlah pengaturan baru sebagai pembahuruan dalam Hukum Perkawinan terkait perjanjian perkawinan yang bisa dilaksanakan selama perkawinan. Selanjutnya, perjanjian tersebut tidak hanya dibuat dan disahkan oleh pegawai pencatat perkawinan tapi dapat pula dibuat di muka notaris dan bisa diubah dan dicabutnya perjanjian mengenai harta perkawinan ataupun perjanjian lain dengan persetujuan suami dan istri sepanjang tidak merugikan pihak ketiga.

Lahirnya ketentuan baru sebagai pembaharuan hukum dalam Hukum Perkawinan ini memberi akibat hukum yang sangat besar bagi aspek-aspek lain dari kehidupan perkawinan terutama menyangkut harta bersama dalam perkawinan. Dengan pengaturan baru pada Pasal 29 UU No.1 Tahun 1974 tersebut maka ketidaktahuan baik calon suami atau calon istri atas perjanjian kawin yang sebelum atau saat dilangsungkan perkawinan tidak dibuat maka dengan ketentuan baru sebagai hasil yudisial review sebagaimana ditentukan

\footnotetext{
${ }^{25}$ Abdulkadir Muhammad, Hukum Harta Kekayaan, Bandung: Citra Aditya Bakti, (1994), hlm. 67.

${ }^{26}$ Loc. Cit.

${ }^{27}$ http://business-law.binus.ac.id/2016/11/30/putusan-mahkamah-konstitusi-terkait-perjanjian-kawin-dalam-undang- undangperkawinan. diakses pada tanggal 10 Mei 2017, jam 10.00 WIB.
} 
dalam putusan Mahkamah Konstitusi (MK) No. 69/PUU-XIII/2015 membuka peluang untuk membuat perjanjian perkawinan dalam berlangsungnya perkawinan jika kepentingannya menghendaki di muka notaris selama undang-undang, agama dan kesusilaan tidak melarangnya.

\section{Asas Tanggung Renteng pada Perusahaan Bukan Badan Hukum dan Akibat Hukum terhadap Harta dalam Perkawinan}

Perusahaan bukan badan hukum sebagaimana diatur dalam KUHD adalah Firma dan CV yang persamaan pokoknya dalam hal adanya sekutu komplementer. Sekutu komplementer adalah pengurus yang aktif dalam pada Firma dan CV yang berwenang untuk menjalankan dan mengembangkan usaha perusahaan agar tercapai tujuan perusahaan berupa keuntungan atau laba bagi perusahaan dan para sekutu pemilik perusahaan. Dengan kewenangan yang diberikan oleh undang-undang maka sekutu komplementer berwenang melakukan hubungan hukum dengan pihak lain atau perusahaan lain melalui perjanjian. Salah satu perjanjian yang dapat berakibat menguntungkan atau merugikan perusahaan adalah perjanjian pinjaman uang. Pinjaman uang yang dapat dikelola dengan baik oleh sekutu komplementer akan menguntungkan perusahaan. Sedangkan pinjaman uang yang tidak dapat dikelola dengan baik akan merugikan perusahaan termasuk merugikan para sekutunya.

Perjanjian pinjaman uang atau dikenal dengan perjanjian kredit dalam praktik perbankan mendudukkan perusahaan atau pihak yang mendapat pinjaman sebagai debitor dan pihak yang memberi pinjaman disebut kreditor. ${ }^{28}$ Dalam hal pinjaman tidak dapat dikembalikan oleh debitor maka terjadi wanprestasi atas perjanjian. Wanprestasi memberi akibat hukum sebagaimana ditentukan dalam perjanjian. Pada umumnya dalam perjanjian pinjaman uang atau kredit, sanksi hukum akibat wanprestasi adalah pemenuhan perjanjian disertai pembayaran bunga karena keterlambatan. Jika debitor tidak menjalankan kembali sanksi hukum yang ditentukan maka upaya hukum dapat dilakukan oleh kreditor berupa gugatan ke Pengadilan Negeri untuk meminta penyelesaian hukum atas wanprestasi debitor. Namun demikian, terdapat upaya hukum lain yang ditentukan oleh Undang-Undang Nomor 37 Tahun 2004 tentang Kepailitan dan Penundaaan Kewajiban Pembayaran Utang (UU No.37 Tahun 2004) yaitu dengan mengajukan permohonan pailit terhadap debitor baik oleh kreditor maupun oleh debitor yang bersangkutan. Pasal 5 UU No.37 Tahun 2004 menentukan bahwa permohonan pernyataan pailit terhadap suatu Firma harus memuat nama dan tempat tinggal masing-masing sekutu yang secara tanggung renteng terikat untuk seluruh utang firma.

Berdasarkan ketentuan Pasal 5 UU No.37 Tahun 2004 secara jelas dan terang dinyatakan bahwa semua sekutu dari suatu firma ikut menanggung utang dari Firma tersebut. Persekutuan memiliki kewajiban untuk membayar semua utangnya, apabila harta kekayaan persekutuan tidak mencukupi, maka setiap sekutu haru membayarnya dengan harta kekayaan pribadi. Hal ini adalah akibat dari tidak ada pemisah antara harta kekayaan persekutuan firma dan harta kekayaan pribadi sekutu. ${ }^{29} \mathrm{CV}$ memiliki ketentuan yang sama juga dengan Firma karena CV adalah Firma dan tanggung jawab sekutu komplementer dari CV sama dengan sekutu komplementer pada Firma.

Pailit merupakan keadaan di mana debitor tidak mampu membayar utang-utangnya kepada kreditor. ${ }^{30}$ Apabila telah terpenuhi syarat-syarat pailit sebagaimana ditentukan dalam Pasal 2 UU No.37 Tahun 2004, maka akan dikeluarkannya putusan Pernyataan Pailit oleh Pengadilan Niaga di tempat kedudukan debitor yang mengalami kepailitan. Dengan terpenuhinya syarat pailit yaitu debitor mempunyai sedikitnya dua kreditor dan tidak mampu membayar paling sedikit satu utangnya yang sudah habis masanya dan dapat ditagih. Pengadilan Niaga dengan putusannya yang ditetapkan akan menempatkan debitor pailit berada dalam kepailitan yang akibat hukumnya yaitu kehilangan haknya untuk menguasai dan mengurusi hartanya yang termasuk dalam harta pailit sebagaimana ditentukan dalam Pasal 24 Ayat (1) UU No.37 Tahun 2004. Selanjutnya dengan pengawasan hakim pengawas, pengurusan dan pemberesan harta debitor pailit dilaksanakan oleh kurator sebagaimana ditetapkan dalam putusan pernyataan pailit Pengadilan Niaga dan diatur dalam UU No.37 Tahun 2004. Dalam hal debitor pailit adalah perusahaan bukan badan hukum yaitu Firma dan CV maka pihak yang bertanggung jawab atas kerugian persekutuan adalah sekutu komplementer dan harta kekayaan sekutu komplementer dengan beban tanggung jawab atas kerugian yang tidak terhingga,

\footnotetext{
${ }^{28}$ Sutan Remy Sjahdeini, Hukum Kepailitan Memahami Undang-Undang Nomor 37 Tahun 2004 tentang Kepailitan, Jakarta: Pustaka Utama Grafiti, (2009), hlm.2.

${ }^{29}$ Ibid., hlm. 32.

${ }^{30}$ M.Hadi Shubhan, Hukum Kepailitan (Prinsip, Norma, dan Praktik di Peradilan), Jakarta: Kencana Prenada Media Group, (2008), hlm.1.
} 
bahkan semua kerugian persekutuan menjadikan kekayaannya sebagai jaminan. ${ }^{31} \mathrm{Hal}$ ini dinyatakan secara tegas dalam Pasal 18 KUHD bahwa "tiap-tiap persero bertanggung jawab secara tanggung renteng untuk seluruhnya atas perikatan-perikatan perseroannya". Ketentuan Pasal 18 KUHD inilah yang menjadi dasar hukum dari berlakunya asas tanggung renteng bagi sekutu aktif atau sekutu komplementer yang dimiliki oleh Firma dan CV.

Pemberlakuan asas tanggung renteng bagi setiap sekutu komplementer yang berasal harta kekayaannya untuk menutupi atau mengembalikan uang pinjaman Firma dan CV terhadap para kreditornya bahkan sampai harta pribadinya dalam hal tidak dilakukan pemisahan harta dengan perjanjian kawin diperkuat pula pengaturannya dalam kepailitan pada Pasal 64 Ayat (1) UU No.37 Tahun 2004 yang menentukan bahwa persatuan harta akan ikut pailit apabila terjadi kepailitan suami atau isteri. Ketentuan Pasal 64 Ayat (1) UU No.37 Tahun 2004 tersebut sejalan dengan ketentuan Pasal 23 UU No.37 Tahun 2004 yang menyatakan bahwa debitor pailit sebagaimana dimaksud dalam Pasal 21 dan Pasal 22 UU No.37 Tahun 2004 meliputi isteri atau suami dari debitor pailit yang menikah dalam persatuan harta. ${ }^{32}$ Ketentuan ini memberikan pengaruh terhadap harta kekayaan perkawinan, karena harta kekayaan suami atau isteri akan terkena sita dan masuk boedel pailit apabila suami atau isterinya pailit.

Pasal 241 UU No.37 Tahun 2004 adalah ketentuan yang merupakan penegasan dari Pasal 64 Ayat (1) UU No.37 Tahun 2004 yang menentukan apabila debitor pailit yang telah menikah dalam persatuan harta maka harta debitor pailit mencakup semua aktiva dan pasiva persatuan. Selanjutnya, Pasal 64 Ayat (2) UU No.37 Tahun 2004 menentukan dengan tidak mengurangi pengecualian sebagaimana dimaksud dalam Pasal 25 UU No.37 Tahun 2004 yang menyatakan bahwa semua perikatan debitor yang terbit setelah putusan pernyataan pailit tidak bisa dibayar dari harta pailit kecuali perikatan tersebut menguntungkannya dan yang berhak menagihnya yaitu kreditor. ${ }^{33}$

Dalam ketentuan umum (lex generalis) Hukum Perdata sebelum berlakunya Undang- Undang Kepailitan, telah diatur pula dasar hukum digunakan bagi sekutu kompelmenter bertanggung jawab atas utang-utangnya terhadap para kreditor sampai dengan harta pribadinya. Hal ini dinyatakan dalam Pasal 1131 KUHPerdata yang menjadi dasar hukum yang menentukan tanggung jawab perdata seseorang atas perikatan utang-utangnya, yaitu "segala kebendaan si berutang, baik yang bergerak maupun yang tidak bergerak, baik yang sudah ada maupun yang akan ada dikemudian hari, menjadi tanggungan untuk segala perikatannya perseorangan." ${ }^{34}$ Ketentuan ini Pasal 1131 KUHPerdata memberikan penegasan bahwa apabila debitor tidak membayar utang-utangnya kepada kreditor, maka hasil penjualan dari harta kekayaan debitor akan dijadikan sumber pelunasan untuk utangnya. Harta kekayaan yang dimaksud dalam Pasal 1131 KUHPerdata adalah harta kekayaan yang dimiliki oleh debitor selaku sekutu komplementer yang ada pada Firma dan CV. Bagi sekutu komplementer yang memiliki harta bersama dalam perkawinannya, maka harta tersebut yang menjadi sumber pelunasan bagi utang- utangnya. Pasal 1131 KUHPerdata mengatur prinsip tanggung jawab orang atas utang-utangnya yang pada asasnya meliputi seluruh harta debitor. Adapun yang dimaksud dengan perikatan dalam ketentuan di atas adalah utang-utang perikatan atau dengan kata lain, kewajiban prestasi perikatan yang berdasarkan Pasal 1234 KUHPerdata bisa dikelompokkan menjadi kewajiban untuk memberikan sesuatu, berbuat sesuatu atau tidak berbuat sesuatu. ${ }^{35}$

Berdasarkan penjelasan tersebut dapat dinyatakan bahwa harta bersama dalam perkawinan sebagaimana diatur dalam Pasal 35 Ayat (1) UU No.1 Tahun 1974 dan ketentuan mengenai pailitnya suami atau isteri yang kawin dalam persatuan harta sebagaimana diatur dalam Pasal 64 Ayat (1) jo. Pasal $241 \mathrm{UU}$ No.37 Tahun 2004 memberi akibat hukum bagi setiap sekutu komplementer pada Firma dan CV yang terikat perkawinan tanpa perjanjian perkawinan demi hukum terjadi persatuan harta maka harta bersama menjadi harta yang dapat disita atau harta pailit untuk beban pembayaran utang bagi para kreditornya. Untuk itu, agar gugatan atau permohonan pailit terhadap sekutu komplementer pada pada perusahaan bukan badan hukum dapat dikabulkan oleh Majelis Hakim Pengadilan Negeri atau Niaga dan dapat diminta bertanggung jawab secara tanggung renteng dari harta bersama dalam perkawinan. Untuk itu,istri atau suami dari sekutu komplementer harus pula turut digugat atau dimohonkan pailit. Dalam hal istri atau suami keberatan atas permohonan pailit tersebut maka dapat mengajukan eksepsi atau jawaban disertai bukti adanya perjanjian kawin.

\footnotetext{
${ }^{31}$ Abdulkadir Muhammad, Op.Cit., hlm.95.

${ }^{32}$ Sultan Remy Sjahdeini, Op.Cit., hlm. 188.

${ }^{33}$ Ibid.

${ }^{34}$ J.Satrio, Hukum Jaminan Hak Jaminan Kebendaan Fidusia, Bandung: Citra Aditya Bakti, (2005), hlm. 4.

${ }^{35}$ Ibid., hlm. 4-5.
} 


\section{Penutup}

Asas tangung jawab tanggung renteng bagi setiap sekutu aktif atau sekutu komplementer dalam hal timbul kerugian kepada pihak lain bersifat tanggung jawab pribadi dan keseluruhan telah diatur secara jelas dalam KUHD. Bahkan tanpa kecuali bagi sekutu aktif yang dilarang melakukan perbuatan hukum tertentu bagi kepentingan perusahaan tetap dibebankan tanggung jawab renteng atas kerugian bagi pihak lain. Namun demikian, dalam praktik dapat diterapkan terlebih dahulu kerugian yang diderita perusahaan ditanggung dari uang kas perusahaan dan selebihnya dibebankan secara tanggung renteng terhadap semua sekutu komplementer dan kewajiban ini tidak dibebankan kepada sekutu komanditer. UU No.1 Tahun 1974 tentang Perkawinan dan UU No.37 Tahun 2004 tentang Kepailitan dan Penundaan Kewajiban Pembayaran Utang telah mengatur dan memberi akibat hukum bagi setiap sekutu komplementer pada Firma dan CV yang terikat perkawinan tanpa perjanjian perkawinan demi hukum terjadi persatuan harta maka harta bersama menjadi harta yang dapat disita atau menjadi boedel pailit untuk beban pembayaran utang bagi para kreditornya. Untuk itu, agar gugatan atau permohonan pailit terhadap sekutu komplementer pada pada perusahaan bukan badan hukum dapat dikabulkan oleh Majelis Hakim Pengadilan Negeri atau Niaga dan dapat diminta bertangung jawab secara tanggung renteng dari harta bersama dalam perkawinan maka istri atau suami dari sekutu komplementer harus pula turut digugat atau dimohonkan pailit. Untuk itu, dalam hal istri atau suami keberatan atas permohonan pailit tersebut maka dapat mengajukan eksepsi atau jawaban disertai bukti adanya perjanjian kawin.

\section{DAFTAR PUSTAKA}

Asyhadie, Zaeny. (2005). Hukum Bisnis Proses dan Pelaksanaannya di Indonesia. Jakarta: Raja Grafindo Persada.

Grafik. Jono. (2013). Hukum Kepailitan. Jakarta: Sinar Grafika.

Hartanto, J.Andy. (2012). Hukum Harta Kekayaan. Yogyakarta: Laksbang

Muhammad, Abdulkadir. (2010). Hukum Perusahaan Indonesia (Cetakan Keempat Revisi). Bandung: Citra Aditya Bakti.

Muhammad, Abdulkadir. (1994). Hukum Harta Kekayaan. Bandung: Citra Aditya Bakti.

Muhammad, Abdulkadir. (2014). Hukum Perdata Indonesia. Bandung: PT Citra Aditya Bakti.

Purwosutjipto, H.M.N. (2005). Pengertian Pokok Hukum Dagang Indonesia 2: Bentuk- Bentuk Perusahaan. Jakarta: Djambatan.

Sjahdeini, Sutan Remy. (2009). Hukum Kepailitan Memahami Undang Undang Nomor 37 Tahun 2004 tenang Kepailitan. Jakarta: Pustaka Utama Grafiti.

Tutik, Titik Triwulan. (2008). Hukum Perdata Indonesia dalam Sistem Hukum Nasional. Jakarta: Kencana. 
